\title{
Hypercitizenship and the Management of Genetic Diversity. Sociology of Law and the Key Systemic Bifurcation Between the RING Singularity and the Neofeudal Age
}

\author{
Andrea Pitasi ${ }^{\bullet}$
}

\begin{abstract}
Riassunto
Questo saggio di tipo teorico si focalizza sulla funzione allocativa dei sistemi legali per attrarre/respingere capitali differenti sulla base delle proprie procedure di creazione di norme e leggi. Tale funzione dei sistemi legali è di primaria importanza al giorno d'oggi dato che il genere umano è prima di tutto una biforcazione evoluzionistica e sistemica che si situa tra il concetto heideggeriano di Gegnet di una convergenza strategica ed altamente rapida (ad esempio, la Singolarità) fra robotica, informatica, nanotecnologie e genetica (RINGs) - che sta ridisegnando la vita umana relativamente ai suoi stili e standard qualitativi di vita con particolare riferimento agli ambiti della salute e dell'ambiente - ed il così detto Scenario Neofeudale (NS) proposto da coloro che ritengono che il Modello Industriale abbia fallito e che l'unica via per salvare il genere umano ed il suo ambiente dovrebbe essere una sorta di viaggio a ritroso nel tempo per riproporre lo stile di vita medioevale caratterizzato da lentezza ed austerità.

Questo saggio ripercorre la più recente ed autorevole letteratura internazionale relativa alle due alternative di biforcazione e prospetta un potenziale mutamento di paradigma nell'ambito dell'approccio sistemico al fine di ristrutturare la mappa concettuale del mutamento globale attraverso un'epistemologia sistemica della sociologia del diritto.
\end{abstract}

\section{Résumé}

Cet essai se focalise sur la fonction allocative des systèmes judiciaires exercée pour attirer/rejeter des capitaux différents sur la base de leur propres procédures de création de règles juridiques et de lois. Cette fonction est aujourd'hui d'une importance fondamentale. En effet, le genre humain est avant tout une bifurcation évolutionniste et systémique entre le concept heideggérien de Gegnet d'une convergence stratégique et extrêmement rapide (par exemple, la Singularité) parmi la robotique, l'informatique, les nanotechnologies et la génétique (RINGs) - qui est en train de redessiner la vie humaine par rapport à ses styles et ses standards qualitatifs de vie et tout particulièrement aux domaines de la santé et de l'environnement - et ce qu'on appelle le Scenario Néo-féodal (NS) proposé par ceux qui pensent que le Modèle Industriel a échoué et que le seul moyen de sauver le genre humain et son environnement serait une espèce de voyage en arrière dans le temps pour proposer de nouveau le style de vie du Moyen-âge caractérisé par la lenteur et l'austérité. Cet essai examine la littérature internationale la plus récente et la plus influente concernante les deux alternatives de bifurcation et avance une modification potentielle de paradigme dans l'approche systémique afin de reformuler la carte conceptuelle du changement global à travers une épistémologie systémique de la sociologie du droit.

\section{Abstract}

This essay is essentially theoretical and is focused on the allocative function of the legal systems to attract/reject different capitals according to their procedures to shape norms and laws. This function of the legal systems is pivotal in our times as humankind is before a systemic and evolutionary bifurcation between the heideggerian Gegnet of a strategic, high speed convergence (i.e. Singularity) among robotics, informatics, nanotechonologies and genetics (RINGs) - which is going to reshape the human life concerning its life quality styles and standards especially regarding health and environment matters- and the so called Neofeudal Scenario (NS) supported by whom the Industrial Model failed and the only way to save humankind and its environment would be a kind of trip back to a Medioeval life style inspired by slowness and austerity.

This essay provides an overview of the most important and recent international references about the two alternatives of the bifurcation and describes a potential paradigm shift inside the systemic approach to reframe the conceptual map of global change through a systemic epistemology of the sociology of law.

\footnotetext{
- Associate Professor at the Gabriele D’Annunzio University, Chieti and Pescara, Italy.
} 


\section{Prologue.}

The emergent convergence/singularity of endotechnologies $^{1}$ thus of the most radically evolutionary outputs of the singularity generated by the convergence of robotics, informatics, nanotechnologies and genetics (RINGs convergence/singularity) is reshaping the social, economical etc patterns and variables of the public understanding of how science and technology are evolving everything around us especially focusing on those key aspects of social life which directly cope with the ultimate frontiers of human evolution, wealth and health.

From this point of view, this theoretical essay deals with the differentiation of the legal systems which are interconnected on a global scale (Globus) (to which every user can access, for example, online, but these legal systems do not represent a unique, homogeneous one inspired by a "universal" vision of law as imposed by the attempts of the past to find law on theology or on an universal concept of rationality as evoked by the Enlightment spirit) nowadays legal systems provide a huge variety of norms and procedures on a global scale shaping a planetary catalogue (Mundus) of norms, concepts, procedures, rules among which a skilled user can easily choose for example in terms of business delocalization/relocalization. Thus the platforms (Globus) and the catalogue (Mundus) of rights available for shopping ${ }^{2}$ on a global scale represent the chance of the legal systems to reveal their most profound identity: they are not based (and probably they never were based) on theological or

\footnotetext{
${ }^{1}$ Nowotny H., Insatiable Curiosity. Innovation in a Fragile Future, Cambridge, USA and London, UK, 2008.

${ }^{2}$ Galgano F., La globalizzazione nello specchio del diritto, il Mulino, Bologna, 2005.
}

rational universality but on the glocal power of will ${ }^{3}$.

From this perspective the Mundus of rights shapes the competition/cooperation among legal systems on the Globus about attracting the key and most strategic capitals (intellectual, financial, human etc ) to empower and evolve at the highest speed the RING Singularity thus the state of the current scientific-technological is extremely differentiated among the various geopolitical and legal areas of our planet. It might seem simplistically but the viability of the Ring Singularity increases according to the specific attractivity of a legal system. Brazil, China, India and Russia (the so called BRIC) are not growing at a higher speed than USA or the UE because they are reproducing our economical model to reach our same wealth level, they are reconfigurating the rules of the business- enterprise- science- technology game by drawing new theoretical- juridical distinctions and new radical operations. That is why the link between RING Singularity (RS) and Legal System Attractivity (LSA) can, and someway must, be reframed though the paradigms shifts form the "human condition" (HC) to the "posthuman" one (PHC) and then to the "hyperuman" one (HHC as the convergent technologies dramatically and powerfully reshape the ideas of humanity and mankind).

What does it mean to be human? When did mankind begin to be human? And when did mankind quit to be human? In evolutionary, Darwinian, terms we might consider we became human when we began to manipulate symbols by using our neocortex and then we began to model and adapt the world our way more than adapting

\footnotetext{
${ }^{3}$ Irti N., Nichilismo Giuridico, Laterza, Roma, 2004.
} 
to it. But when did it happen? When we were CroMagnon, Neanderthal or at the homo sapiens stage? Or maybe we were naturally human before we learned to "create our own world" thus before we began to use fire ${ }^{4}$ and since we started to use fire we began an artificialization process (clothes to protect ourselves from the cold weather, glasses to correct sight problems up to the most advanced cardiosurgery technologies) which represents a post humanization of the human toward the "cyborg" so that human life can last longer and under better quality conditions by replacing “ broken parts" with new, efficient, artificial ones? Is a man with a pacemaker human or is he an evolutionary stage of the cyborg?

If we take a look at the Bible the perspective might sound different at a first glance but in practice is not. While the Neanderthal was probably "less human" than the homo sapiens but Adam and Eve were some way "extrahuman" or "superhuman" as they had not the key weakness which features what commonsense nowadays would call $\mathrm{HC}$ for Adam and Eve becoming human was a kind of downsizing and according to the Bible they became human because of the original sin. Both in an evolutionary Darwinian perspective and in a Christian one, at a certain point we became human and this implied to learn, to create and to increase knowledge in order to model the world according to our needs/hopes/fears and so on. Either emerging from the cavern or falling from the Lost Eden, mankind is featured by an artificialization process towards the Cyborg, the PHC, if we consider

4 Goudsblom J., Fire and Civilization, Penguin, London, 1994. human history $^{5}$ but then, all in a sudden, something changed and the HHC began to take shape exactly when the RING Singularity started to evolve faster and faster, tendentially since the end of World War I. But what is HHC featured by?

Probably, the two most brilliant analysis of the HHC are provided by Helga Nowotny in her superb Insatiable Curiosity ${ }^{6}$ which is an excellent work in the sociology of science and by John Harris excellent book Enhancing Evolution ${ }^{7}$ author who is a thought leader of the British sociology of Law at the Law School of the University of Manchester

Both books cope with two aspects. The technological convergence named RING Singularity and the way it will reshape social organization and its rules. Nowotny ${ }^{8}$ provides the key concept of scientific citizenship "which I consider pivotal to link Globus and Mundus, as the scientific citizen is the user both of the $G$ platform and of the $\mathrm{M}$ catalogue by selecting those rights which fit more with his/her wealth, health and well being needs.

Due to the convergence between the RING Singularity and the most attractive legal systems on the planet our species seems to have already had an internal differentiation among:

i) Humans

ii) Posthumans or Cyborgs

iii) Hyperhumans.

This is the key challenge about diversity management nowadays. Gender diversity or racial

\footnotetext{
${ }^{5}$ Goudsblom J., Nichilismo e cultura, il Mulino, Bologna, 1982.

${ }^{6}$ Nowotny H., op. cit.

${ }^{7}$ Harris J, op. cit.

${ }^{8}$ Nowotny H., op. cit.
} 
diversity seem and are rather irrelevant in comparison.

It is not hard to say that "humans" no longer exist since, at least we might correct our sight problems by using spectacles.

We all are already cyborgs or posthumans either because we are partially artificial and maybe in our body we have cyborg installations such as pacemakers or because we share the same memetic scenario in which we are perfectly aware we might host these installations inside us. Our brainframe is always posthuman and much more posthuman than what our body might be in practice in the present time. We all are conceptually posthuman.

But if "humans" died at a average age of 30 , posthumans can live about 75/85 years as an average with some exception up to $100 / 105$. The HHC is radically different, as clearly described by Harris $^{9}$ a $\mathrm{HH}$ person can live about $120 / 130$ years as an average if (s) he belongs to the first HHC generation (born around 2006) or about 740 years as an average (yes, it is not a type, seven hundred and forty years) if (is) he belongs to the second HH generation born around 2015-2020). What is all the fuss about this paradigm shift by reshaping the "person" through the link between RS and LSA?

Essentially, the first $\mathrm{HH}$ generation represents the stem cell re-entry in the health risk prevention and reduction but some way reinstalling "baby cells" in a sick body its own stem cells (deriving from its own umbilical cord perfectly safed by a genetic bank ). Thus the installation is "natural" and "clean" not artificial but the installation process itself remains a typical post human working style.

\footnotetext{
${ }^{9}$ Harris J, op. cit.
}

A sort of triple helix of complexity empowerment- high speedy evolution matchfinding ease between RS and LSA is the key of the way the two species( $\mathrm{PH}$ and $\mathrm{HH})$ are distributing themselves through the planet and is also the key of the human re-entry clearly theorized and wonderfully argumented by Archer ${ }^{10}$ and Donati ${ }^{11}$.

Complexity, Speed and Ease are the "stars" of the radical reconfiguration ${ }^{12}$ process reshaping social life in its broadest and deepest meaning.

From this point of view, nine turboconditions seem pivotal to assess the LSA for the RS.

\section{What's Next?}

The gap between the two $\mathrm{HH}$ generations brilliantly describes how radical technological innovation powerfully reconfigurates individual, personal Lebenslauf and systemic organization. The $\mathrm{HH}$ shift also involves $\mathrm{HH}$ agriculture (the GMOs, for example) and the $\mathrm{HH}$ energy agenda. This HH shift dramatically provokes strong public opinion debates and their "consequences" easily witness that emotional, incompetent reactions and attitudes simply generate a growing public misunderstanding of science, technology and their socio-economical impacts. That is why scientific

10 Archer M., La conversazione interiore, Erickson, Trento, 2006; Id., La morfogenesi della società, Franco Angeli, Milano, 1997; Id., Riflessività umana $e$ percorsi di vita, Erickson, Trento, 2009; Id., Essere Umani, Marietti, Genova, 2010.

11 Donati P., La famiglia nella società relazionale, Angeli, Milano, 1987; Id., Teoria relazionale della società, Angeli, Milano, 1991; Id., La cittadinanza societaria, Laterza, Roma- Bari, 1993; Id., Oltre il multiculturalismo, Laterza, Roma-Bari, 2008; Id., Laicità. La ricerca dell'universale nelle differenze, il Mulino Bologna, 2008; Id., La società dell'umano, Marietti, Genova, 2009; Id., La matrice teologica della società, Rubbettino, Soneria Mannelli, 2010; Id., Relational Sociology, Routledge, London, 2010.

12 Normann R., Ridisegnare l'impresa, Etas, Milano, 2002. 
citizenship is emerging faster and faster to solve the "incompetence" problem, the scientific citizenship is reconfigurating itself and is emerging as a shape of the societarian one ${ }^{13}$ inspired by an autonomous, self organizing "spirit" and mood of the most competent and skilled knowledge based elites educated according to the most self reflexive relational responsible freedom. These elites will be the wide horizon leaders serving as "drivers" of the new cycles and trends: whose trajectories follow the $\mathrm{S}=\mathrm{R} / \mathrm{W}$ formula where the supply/demand match finding between RS and LSA is in real time in the Time Zero of Desire (TZD) scenarios.

To understand these new trajectories clearly described by Harris ${ }^{14}$ and Nowotny ${ }^{15}$ it is adequate to go through Nowotny's work which perfectly shows the paradigm shift from the post human to the hyperhuman scenarios of the RING Singularity in the TZD Age. In Nowotny's semantics, The RING Singularity is labeled as "convergent technologies" which are endotechnologies. The Ring Singularity/Convergent Endotechnologies shape the Hyperhuman World while Exotechnologies are the most evident output of the Posthuman, "Cyborg" scenarios.

Nowotny clearly states that:

"The convergent technologies based on successful connections among the biological, informational, nano, and cognitive sciences open up a broad field in which brain and matter, body and environment can interact in a controlled fashion. These and other transformations that spring from science and technology touch on humanity's self- understanding as much as they change our social life together"16.

Nowotny's key contribution evolves into the concept of scientific citizenship which features the knowledge based society, as a matter of fact, she states:

"A knowledge based society also increases its production of epistemic things, various kinds of abstract objects, and technical artifacts that are subject to the same rules. The democratization of scientific expertise is also merely the expansion of principles of governance that have served the Western liberal democracies well. Today, science and technology are no longer viewed with awe but are part of everyday life. Mediated by the educational system and qualifications and certificates people acquire, they determine people's chances of upward social mobility, their working world, and the course of their biographies. It is thus logical to extend the concept of citizenship to science and technology. «Scientific citizenship» comprises right and duties and asks about both the functions that expanded concept of citizenship could fulfill in social integration and also the duties that arise from it for citizens as well as for political institutions and administrations" $"$.

Nowotny suggests that:

"There is broad agreement that more money should be invested in research (that is, that science and technology must continue to expand). This is to be achieved by putting the unexpected and new that comes out of the laboratory into the widest possible variety of contexts of applications to produce in them new knowledge that in turn

\footnotetext{
${ }^{16}$ Ivi, pp. 12-13.

${ }^{17}$ Ivi, pp. 23-24.
}

\footnotetext{
${ }^{13}$ Donati P., La cittadinanza societaria, cit.

${ }^{14}$ Harris J, op. cit.

${ }^{15}$ Nowotny H., op. cit
} 
brings forth new abilities and continues to spread in society" $"$.

\section{Moreover:}

"Today, the entire knowledge of humankind and its impressive technological capacities is oriented toward a future that does not so much promise a new beginning as further intensification and dynamic continuation of what has already been achieved. Science and technology cross the threshold between the present unhindered, for what appears possible in the laboratory today can already be in the market tomorrow or the day after" $" 19$.

What's next, then?

"The future we are now face relies on innovation under conditions of uncertainty. This cannot be equated with lack of knowledge - quite the contrary. Uncertainty arises from the surfeit of knowledge, leading to too many alternatives, too many possible ramifications and consequences, to be easily judged"20.

In practice:

"Exotechnologies aim at the expansion of possibilities of controlling the environment. They have enabled people to travel greater differences in less time and to settle the space they found more densely and efficiently. The processing of found and extracted materials finally enable the mass production of artifacts, the preservation of foodstuffs, and the erection of infrastructures that in turn made it possible to live comfortably in otherwise inclement climate zones. In contrast, the regime of endotechnologies - bio-, nano-, info-, and other converging technologies - changes the dimensions and scope of action of the scientific objects. They form mostly invisible yet visualizable infrastructures that can penetrate into the smallest dimensions of matter or living organisms",21.

Thus:

"Science and technology cross the boundary between the present and the future with a certain ease and thereby move the future closer the present. Nonetheless the future seems fragile. The loss of temporal distance blurs the difference between what is technologically possible and what is already present in the laboratory, between imagination and reality, which is often a virtual reality. Having lost all utopias, the future presents itself as a sketch of technological visions that block out the social knowledge that is needed to live in a scientific-technological world - and to feel well in it",22.

\section{Complexity.}

We are currently heading towards wider and faster scenarios. This kind of evolution we are getting through is also due to decrease of "dead woods" (made up of useless infrastructures, lazy employees and parasites) due to "bipartisan" public reforms already implemented since the early 90's.

These scenarios will make cultural and trade exchanges easier and quicker. Furthermore, they will be safer and more stable, thus to eliminate any "interferences" to global flows of human, intellectual and economic capitals on a worldwide scale, since socio-economic challenges of our times cannot be managed on a national or even local level.

\footnotetext{
${ }^{21}$ Ivi, pp. 132-133.
}
${ }^{22}$ Ivi, pp. 155-156.
${ }^{18}$ Ivi, pp. 83,84 .
${ }^{19}$ Ivi, p. 107.
${ }^{20}$ Ivi, p. 116. 
Higher levels of speedy and safety will then characterize the new scenarios as a new jumbo jet in comparison to older plane models which are more instable and slow.

This stable "speed" mostly depends on the development and broadcasting of new and standardized platforms, procedures and technologies (currency, languages, operative systems) that can create transparency (i.e. through video recordings, metal detectors, etc.).

I personally define this stable and fast scenario the "Time Zero of Desire" (TZD) because it represents the kind of scenario in which supply and demand (of material, relational and economic goods) can easily cross at the same high speed of emails or sms exchange. TZD is then perceived as a high speed scenario which is stable in crossing supply and demand at the lowest economic, organizational and contractual costs.

The setting showed above is developing according to an increasing number of turbo-economies (from India to Botswana) more and more global and transparent in nature. Those economies put in evidence some areas of the world scene that are generally not strategic and in which we can often see provincial and narrow minded attitudes. The latter are similar to the behaviour of some ancient feudal lords who used to threaten and scare their own subjects by means of fear and ignorance. Thus, they would prevent their people from experiencing the real society, by keeping them inside the feud, afraid of facing some alleged external dangers from which the local power could not protect its subject anyway.

TZD is the ultimate scenario to implement turbocondition, described as follows:
TURBOCONDITION 1: To Reset the reptilian brain.

We assume as true the theory of the evolution through interconnected balances which is based on the cooperation of three brains belonging to any human being: reptilian, limbic and neocortex. Besides, we keep in mind the man's neocortex power as well as the social function of the limbic system. Therefore, the actual issue is whether the way out of the Palaeolithic (i.e. a condition of radical bound to roots and homeland which is typical of nowadays "cave men") would also mean to reset the obsolete and harmful reptilian brain. This process leads to show the religions and philosophies adopted according to their functional role which is made up of adaptive methods and behavioural pragmatics.

TURBOCONDITION 2: Evolving the 7 platforms of the global development.

Resetting the reptilian brain necessarily implies erasing the clashing factors generated from this pattern brain, thus to be able to develop the 7 platforms of the global development:

1) Currency and rating standards;

2) Digital satellite telecommunications;

3) Biotechnologies;

4) Extra-planetary technologies;

5) Technical-linguistic platforms;

6) Contents catalog;

7) Evolutionary capitalism.

This strive for development represents a strategic function in the policymaking agenda.

TURBOCONDITION 3: To increase the moral and ethic significance of the economic development avoiding financial bubbles.

The increasing trend to the institutionalization of "neo-rights" is not often adequately followed by a 
feasibility analysis in order to apply it. Besides, other elements are lacking, such as the creation of new professional profiles, procedures and structure that can support the process of implementation and that can lead to those speculative bubbles which are attributable to political rather than economic behaviours ${ }^{23}$.

Contemporary politics should avoid to let an empty rhetoric of some sort of newly rights create two kinds of negative conditions:

1. Illusions unheard consequently provoking social conflicts;

2. Obstacles to ongoing development processes

This can be obtained exclusively regaining the ethic value of development, trying to implement new markets and pushing the progress through Kuhnian evolutions, without any interruption of the productive cycle.

TURBOCONDITION 4: To place the political sphere among economic businesses of the service sector. Politics has always been supported by trade exchanges and not just because of a sort of influence peddling.

Politicians do marketing, they exploit the "hic et nunc" philosophy and go along with structures and entities that can provide consent in the short term.

The political system sets up a sort of market which is actually highly inflated and with a scarce added value, and which produces plenty of financial and propagandist bubbles every time that some legislature report is required. Therefore, other institutions and systems apart from the

\footnotetext{
${ }^{23}$ See the 1995 amendment of the US Community Reinvestment Act, as described in my article "I BARACKATI"

http://www.tuttocomunicazione.it/index.php?option=co m_content\&view=article\&id=92: managcomstra\&catid =43:rubriche\&Itemid $=65>$
}

market do exist, and behave like an economic reality since they promote business speed, customer satisfaction, process innovation, even though they are based on an inflation and implosive logic, with high costs and minimum value added. Politics belong to this kind of systems.

TURBOCONDITION 5: To give policymaking opportunities to scientists, neo humanists and top brainworkers.

Giving political opportunities to eclectic and scientifically qualified intellectual elites would lead the socio-economic development of the knowledge society. Thus to trigger a virtuous circle among power, knowledge and capital and ensuring a real sustainable development.

Notwithstanding the fact that the future evolution will be extremely "technocratic", one should clarify whether this technocracy will be managed by unskilled professionals or experts. The latter acting in Turbocondition as "top brainworkers", that is to say people that concretely work for the development. Their contribution is contemporary intellectual according to the meaning of "neo humanists" ${ }^{24}$, i.e. scholars of human sciences through scientific premises which better enhance a radical innovation instead of an incremental one. Therefore, the above mentioned virtuous cycle can be triggered only if we provide this kind of possibility to people able to think about the opportunities offered by modern scientific paradigms by following different patterns.

TURBOCONDITION 6: To stimulate the subsequent evolution of life on earth focusing on the analysis of the neocortical morphogenesis.

\footnotetext{
${ }^{24}$ Cfr. Brockman in: www.edge.org
} 
Men always interact with their technological tools and the latter can even manipulate our ability to manage them and our lives. This kind of circular dynamic influences should lead to reassess our paradigms about the concept of person and of relational system tout court. According to this new paradigm technical- human like we can make an attempt to understand how the paleocortality and the neocortality are affected by the technical supports and their evolutions.

Perhaps one day we could affect the cortical evolution by means of technology, or even find out that this human corticality has always made some evolutionary leaps thanks to technology. Thus, our way to approach the study of history could change. Our future also depends simply on a new look to daily things.

\section{TURBOCONDITION 7: To encourage}

continuous Kuhninan evolutions and inventions with a high value added.

It is time to encourage continuous Kuhninan evolutions and inventions with a high value added, thus to set grounds for a social system in which, if $\mathrm{S}=\mathrm{R} / \mathrm{W}$, economic cycles follow one after the other with delayed positive timing and shorter depression times in each cycle. V represents speed, $\mathrm{R}$ stands for a model of innovation information broadcast according to Everett Rogers' thought and W refers to Williamson's models. According to Rogers, at an earlier stage innovation is kept by a narrow number of innovators and from them it moves towards the first innovators (connectors, experts and skilled sellers), then it goes to the first majority and finally it reaches the last group of users, i.e the "marginal" ones. Besides,
Williamson states that every organization has to face three types of costs in order to survive:

- $\quad$ Contractual costs;

- $\quad$ Economic costs;

- Organizational costs.

The present turbocondition implies that the ability to spread innovation gets faster as Williamson's costs decrease: it is then necessary to keep costs as low as possible in order to make innovation broadcast faster. Shooting down costs determines new possibilities and also allows other marginal categories to enjoy the use of an innovation without being cut off.

TURBOCONDITION 8: To consider the surplus of variety and the hypercomplexity, a sign of wealth and a big opportunity also in the case of the increasing variety of artificial biodiversities

An eventual collision among natural biodiversity evolutionary systems and those characterized by artificial biodiversity could lead to an hybridization. This is actually already happening (one can think about the fertility control through the birth control pill or to the cure of some decease by means of some genetic alterations).

In fact, the biological turning point offers plenty of opportunities for the life quality on earth, as well as many social issues and new communication needs. That is why this phenomenon is nowadays perceived with great and often unjustified fear. According to Luhmann's, then, "we do not live in best possible world but in a world full of better possibilities", of which we should take advantage.

TURBOCONDITION 9: To enhance competition capitalism on the short and middle term dimension through tactic models such as lean thinking and the kaizen practice 
The lean thinking is addressed to the optimization and to increasing the results performance and has always been opposing against the bureaucratic thought which is based on the control and validation of the procedure.

Striking out wastes can e possible if we pursue and implement 5 principles:

1) To individuate the value;

2) To individuate the flow;

3) To let the flow made up of creating activities run;

4) To make the flow being pulled by the customer, allowing him to purchase the ability to plan and implement only what he wants in the moment in which he wants it (just in time);

5) To look Perfection (Kaizen) in the sense of "continuous improvement".

Rather than an instrument, the lean thinking is a way of thinking which is necessary to activate the $\mathrm{S}=\mathrm{R} / \mathrm{W}$ function.

The 9 turbocondition explained above are necessary, even though not always sufficient to carry out a global scenario. The latter being stable, fast and aware that in a free, open, fast and tolerant world a rapid economic development is a guarantee for a human, personal and social dignity.

The trick according to which a "poor but happy" world can still exist is typical of nowadays cave men that we can easily leave behind trying to light a fire with some wooden sticks while we are sipping our drink, reading a good book and listening to some nice music on a jet carrying us where we wish to go.

These turboconditions facilitate the increasing of the evolutionary speed related to an increase of variety. It might sound paradoxical that increase of variety and increase of speed might walk one beside the other but it is not so as I am going to show below:

\section{Speed.}

The power of complexity and variety meant as a key wealth evolution system is described by the systemic approach by comparing Laszlo's whole/part paradigm and Luhmann's system /environment one to observe the energy-ecology link from an evolutionary perspective. Nevertheless exceeding variety and complexity might activate Buradization loops which is pivotal to avoid. The challenge to avoid these loops largely depends on the speed of the innovation cycles as I am going to explain below

The paradigm shift from whole/part to system/environment is pivotal within system theory because it turns the concept of future upside down. As a matter of fact, the former paradigm still copes with the problem to describe/foresee the future and with the matter of predictability and its variables while the latterwhich is the core of this paper considers the future as conceptual, abstract model which can be invented and then self reproduced but not foreseen/predicted.

In the age of simulation and modeling patterns, the future becomes a an autopoietic concept which evolves self referentially though all the viable networks in which it can reproduce itself. That is why in Luhmann's words: "For a theory of autopoietic systems, only communication is a serious candidate for the position of the elementary units of the basic self referential process of social systems ${ }^{, 25}$.

\footnotetext{
${ }^{25}$ Luhmann N., Essays on self Reference, Columbia University Press, New York, 1990, p.6.
} 
The evolutionary autopoiesis depending on the "reproducing by differentiating" process is a key idea to focus on how the paradigm shift from the whole/part variant to the system/environment one changed the kind of mathematics to be adopted from predicting to modeling, some way from abstract to embodied ${ }^{26}$ mathematics with the aim to frame the most intangible but nevertheless high impact factors of the social systems in the conceptualization of time in general and future in particular. A n exemplary item of intangible but high impact factors of the autopoietic process are the transactional costs especially the organizational ones according to Williamson 's theory related to Roger's cycle for the diffusion of inn ovations in a social system ${ }^{27}$ The Rogersian Cycle (R) Speed (S) is proportionally inverted to the Williamson's costs (W) thus $S=R / W$

The purpose of this essay is to deal with the energy management matter within a systemic approach trying to empower an embodied mathematics viable to fuel the autopoiesis process to increase the R's viability by decreasing $\mathrm{W}$.

26 Lakoff G., Nunez R. E., Da dove viene la matematica, Bollati Boringhieri, Torino, 2005.

${ }^{27}$ Pitasi A., Teoria sistemica e complessità morfogenetica del capitalismo, Aracne, Roma, 2010.

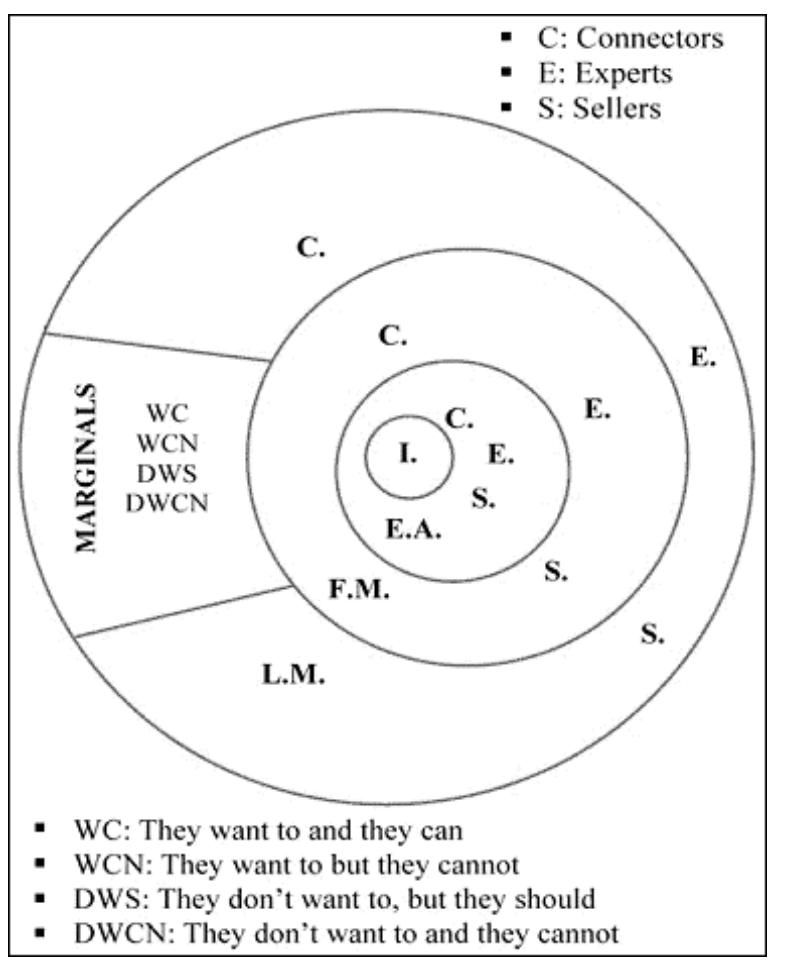

Figure 1: Rogers model updated (Pitasi, 2007)

The key point is to distinguish the differences which can really make the difference to empower the energy system and to go beyond the limits of the pro-oil/contra oil, pro-nuclear/contra nuclear mass media debate. As I widely argumented in some previous works of mine ${ }^{28}$, there are three key features which can increase R's viability complexity, speed, ease. This three features allow $\mathrm{R}$ to generate as a spin off a knowledge wealth flow (KWF) of the energy sector which would be dramatically reconfigured by the KWF itself:

28 Pitasi A., Sfide del nostro tempo, Aracne, Roma, 2007; Id., Teoria sistemica e complessità morfogenetica del capitalismo, cit.; Pitasi A., Ferone E., Il tempo zero del desiderio, McGraw Hill, Milano, 2008. 


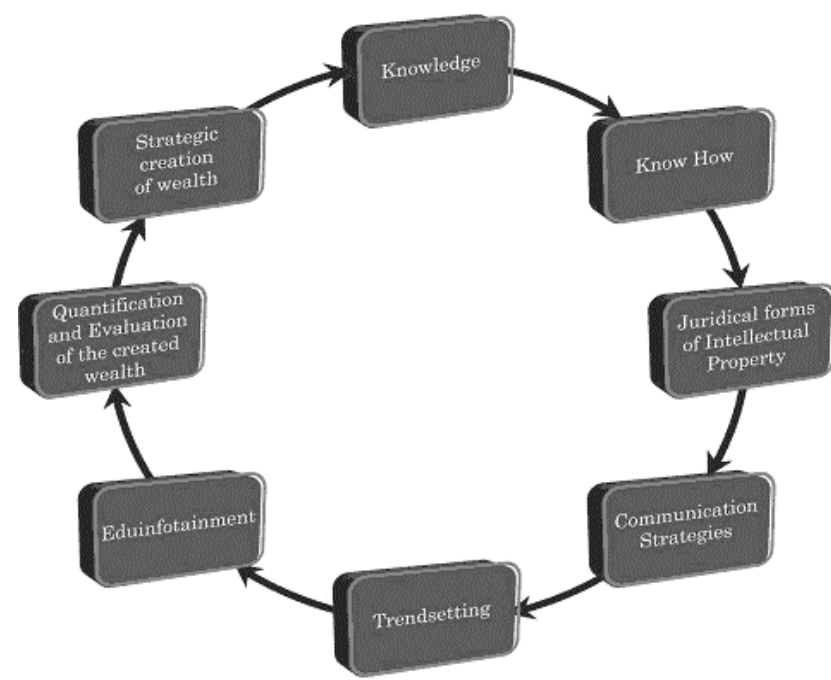

Figure 2: Knowledge and Wealth Flow (Pitasi, 2007)

Let's describe the three key features in brief:

\section{4a. COMPLEX}

Linear, causal models do not work anymore to analyze global changes. The challenges of complexity originally described by Nicolis and Prigogine begin to focus on what kind of mathematics is viable to deal with exceeding varieties and on how much knowledge intensive and information rich a strategic benchmark for energy management might and should be .

\section{4b. HIGH SPEED}

By evolving the $\mathrm{S}=\mathrm{R} / \mathrm{W}$ formula thus by describing the different energy Roger's cycles through the downsizing of Williamson's costs this paragraph will describe how a strategic and effective strategy for energy management would increase socio-economical development, business speed and radical innovation diffusion. Thus it is not difficult to state and demonstrate the loosing mood of those ideologies which link sustainability to growth decreasing and /or a "back to the pre industrial world economy".

4c. EASE
An effective energy management problem solving requires easy and user friendly, almost idiot proof, solutions.

The impact of design (for example about packaging) on recycling policies is a very clear case.

One further example is represented by high concept + eduinfotainment novels such as Crichton's State of Fear through with education, information and entertainment arte mixed and balanced to facilitate- thus the public understanding of science about the key challenges of our times concerning the energy-ecology link.

\section{Conclusions: The Road Ahead.}

The evolution of the variety/speed relationship in terms of $S=R / W$ is a key challenge of our time and an adequate epistemological, theoretical methodological and technical toolkit to empower $\mathrm{S}$ is fundamental. Diversity Management might become a privileged tool to generate win/win variety/selection/stabilization processes by widening the observation horizons, increasing freedom of choice and implementing effective high speed decision making.

From my theoretical perspective ${ }^{29}$ it is pivotal that some key morphogenetic traits of capitalism emerge downsizing other traits which might generate non only risky but also dangerous effects:

In brief:

a) The emergence of the Hyperhyuman shift will probably create new organizational stages of capitalism radically reshaping health policies, food production and so on and this shift represents a potentially wonderful strength towards a more

29 Pitasi A., Teoria sistemica e complessità morfogenetica del capitalismo, cit. 
democratic diffusion of high added value knowledge though the most effective practices of the scientific citizenship lobbying.

b) A key weakness of this shift might be its implosion into the so called techno-nihilist capitalism $^{30}$.

c) The " back to the cavern"/neofeudal solution is not viable at all. As a matter of fact, for example, the pre-industrial agriculture fed less than $50 \%$ of the world population composed of 700/800milion people and the average life length was about 35 years. If we got "back to the past" many old problems of the past would return and a pre-industrial agriculture would feed again about 400 million people that is less than $1 / 16$ of the world population. No viable future might look like our past. Against all odds and against the rhetoric of the ecological threat, "progress" has evident side effects but it definitely works.

d) The scientific citizenship is more and more pivotal to provide democratization in the knowledge sharing process worldwide and it depends on the $\mathrm{S}=\mathrm{R} / \mathrm{W}$ of the relational networking emerging by societarian citizenship $^{31}$ patterns to let the huge variety of scientific information and legal procedures to use them adequately and fairly.

e) The "fair use" of scientific citizenship in a relational, global network depends on the challenge of letting the scientific citizens become free and responsible persons ${ }^{32}$ to provide an adequate re-entry of the human ${ }^{33}$.

\footnotetext{
30 Magatti M., Libertà Immaginaria, Feltrinelli, Milano, 2009.

31 Donati P., La cittadinanza societaria, Laterza, Roma- Bar, 1993.

${ }^{32}$ Cesareo V., Vaccarini I., La libertà responsabile, Vita e Pensiero, Milano, 2006.

${ }^{33}$ Donati P., La società dell'umano, Marietti, Genova, 2009.
}

From this perspective, sociology of law is pivotal to cope with challenge of linking scientific citizenship and societatian citizenship so that the Hyperhuman spin-off of the so called Immortals ${ }^{34}$ might be framed within a relational and responsible legal theory focused on the re-entry of the human in that new shape of global policymaking I call Hypercitizenship.

\section{Key References.}

- $\quad$ Akerlof G., Racconti di un Nobel per l'economia, EGEA-Bocconi, Milano, 2003.

- $\quad$ Alberoni F., Movimento e istituzioni, il Mulino, Bologna, 1977.

- Alesina A., Ichino A., L'Italia fatta in casa, Mondadori, Milano, 2009.

- Alexander J.C., Teoria sociologica e mutamento sociale, Franco Angeli, Milano, 1990.

- $\quad$ Altmann G., Koch W.A., New Paradigms for the Human Sciences, De Gruyter, Berlin-New York, 1998.

Anderson C., La coda lunga, Codice Editore, Torino, 2009.

Archer M., La morfogenesi della società, Franco Angeli, Milano, 1997.

- Archer M., La conversazione interiore, Erickson, Trento, 2006.

- $\quad$ Archer M., Riflessività umana e percorsi di vita, Erickson, Trento, 2009.

- Archer M., Essere Umani, Marietti ,Genova 2010.

- Ardigò A, Per una sociologia oltre il postmoderno, Laterza, Bari, 1988.

- Atlan H., Tra il fumo e il cristallo, Hopefulmonster, Firenze-Torino, 1986.

- Bakken T., Hernes T., Autopietic Organization Theory, Abstrakt Forlag, Copenhaghen, 2003.

- Barzelton B., Greenspan S., I bisogni irrinunciabili dei bambini, Cortina, Milano 2001.

- $\quad$ Bell J. S., Dicibile e indicibile in fisica quantistica, Adelphi, Milano, 2010.

- Blackmore S., La macchina dei memi, Instar Libri, Torino, 2002.

- Blanchard O.J., Fischer S., Lectures in Macroeconomics, MIT Press, Cambridge, 1989.

\footnotetext{
${ }^{34}$ Harris J, op. cit.
} 
- Bloor D., La dimensione sociale della conoscenza, Raffaello Cortina Editore, Milano, 1994.

- Bolz N., Die Wirtschaft des Unscihtbaren, Econ Verlag, Muenchen, 1999.

- Boston Consulting Group, Globality, Rizzoli, Milano 2009.

- Boudon R., The Unintended Consequences of Social Action, New York: St. Martin's Press 1982.

- Brockman J., The Third Culture, Edge Foundation 1991.

- $\quad$ Brockman J., I nuovi umanisti, Garzanti, Milano 2005.

- Capra F., Punto di svolta, Feltrinelli, Milano 1995.

- Cascavilla M., Diritto e morale nell'età dell'Illuminismo, Giappichelli, Torino, 2006.

- Castellano C., Costruzione sociale dell'identità femminile pluralismo giuridico, Aracne, Roma, 2008.

- Cerroni A., Homo Transgenicus, Franco Angeli, Milano, 2003.

- Cesareo V., Vaccarini I., La libertà responsabile, Vita e Pensiero, Milano 2006.

- Chaitin G. Castellano C., Costruzione sociale dell'identità femminile e pluralismo giuridico, Aracne, Roma, 2007.

- Chaitin G., Teoria algoritmica della complessità, Giappichelli, Torino, 2006.

- Chaitin G., Alla ricerca di omega, Adelphi, Milano, 2007.

- $\quad$ Cipolla C. M., Allegro ma non troppo, il Mulino, Bologna 1988.

- Clark A., "Cyborg nati?", in Brockman J. (a cura di), I Nuovi Umanisti, Garzanti, Milano 2005.

- $\quad$ Crozier M., État modeste, état moderne. Stratégie pour un autre changement, Fayard, Paris, 1986.

- $\quad$ Crozier M., La crisi dell'intelligenza. Saggio sull'incapacità delle élites a riformarsi, Edizioni Lavoro, Roma, 1996.

- Dahrendorf R., Per un nuovo liberalismo, Laterza, Roma-Bari, 1993.

- Dawkins R., Il gene egoista, Mondadori, Milano, 1976.

- Dawkins R., "Introduzione", in Blackmore S., La macchina dei memi, Instar Libri, Milano 2002.

- Dawkins R., Il cappellaio del diavolo, Raffaello Cortina Editore, Milano, 2004.

- De Soto H., Il mistero del capitale, Garzanti, Milano 2001.
- Delattre P., Teoria dei sistemi ed epistemologia, Einaudi, Torino, 1984.

- Dennett D.C, L'idea pericolosa di Darwin, Bollati Boringhieri, Torino , 2004.

- Dennett D.C., L'evoluzione della libertà, Raffaello Cortina Editore, Milano, 2004.

- Dennis K., Urry J., After the car, Politry Press, Malden, 2009.

- Donati P., La famiglia nella società relazionale, Angeli, Milano 1987.

- Donati P., Teoria relazionale della società, Angeli, Milano 1991.

- Donati P., La cittadinanza societaria, Laterza, Roma- Bari 1993.

- Donati P., Oltre il multiculturalismo, Laterza, Roma- Bari, 2008.

- Donati P., La società dell'umano, Marietti, Genova, 2009.

- Donati P., La matrice teologica della società, Rubbettino, Soneria Mannelli, 2010.

- Donati P., Relational Sociology, Routledge, London, 2010.

- $\quad$ Donati P. (a cura di), Laicità. La ricerca dell'universale nelle differenze, il Mulino Bologna 2008.

- Dornbusch R., Le chiavi della prosperità, Egea, Milano 2001.

- Downing D., Dictionary of Mathematics Terms, Baron's Educational Series, New York, 2009.

- $\quad$ Drucker P. F., Il management, l'individuo, la società, Franco Angeli, Milano, 2002.

- $\quad$ Ehrlich E., I fondamenti della sociologia del diritto, Giuffrè Editore, Milano, 1976.

- Febbrajo A., Sociologia del diritto, il Mulino, Bologna, 2009.

- Ferrari V., Funzioni del diritto, Laterza, Roma-Bari, 1997.

- Ferrari V., Diritto e società, Laterza, Roma-Bari, 2006.

- $\quad$ Florida R., The Rise of the Creative Class: And How It's Transforming Work, Leisure, Community and Everyday Life, Basic Books, 2003.

- $\quad$ Ford D.H., Lerner R.M., Teoria dei sistemi evolutivi, Cortina, Milano, 2005.

- Friedman B., Il valore etico della crescita, Università Bocconi Editore, Milano, 2008.

- Friedmann D., L'ordine del diritto, il Mulino, Bologna, 2004.

- Fukuyama F., Our Posthuman Future, Picador, New York, 2003.

- Galgano F., La globalizzazione nello specchio del diritto, il Mulino, Bologna, 2005. 
- Gallino L., L'incerta alleanza, Einaudi, Torino, 1992.

- $\quad$ Garreau J., Radical Evolution, Sperling \& Kupfer, Milano, 2007.

- Giner S., El futuro del capitalismo, Peninsula, Barcelona, 2010.

- Goldthorpe J.H., Sulla sociologia, il Mulino, Bologna, 2006.

- Goudsblom J., Fire and Civilization, Penguin, London 1994.

- Gowers T., Matematica, un'introduzione, Einaudi, Torino, 2004.

- Habermas J., Luhmann N., Teoria della società o tecnologia sociale, Etas Kompass, Milano 1973.

- Haken H., Information and Self Organization, Springer, Berlin, Heidelberg and New York, 2006.

- $\quad$ Harris J., Enhancing Evolution, Princeton University press, Princeton 2007.

- Hauser M.D., The evolution of communication, MIT Press, BradfordBooks, Cambridge, 1996.

- Hayek F. , La via della schiavitù, Rusconi, Milano, 1995.

- Heilbronner R.L., Thurow L.C., Capire l'economia, il Sole24Ore, Milano, 2003.

- $\quad$ Hirschman A.O., Felicità privata, felicità pubblica, il Mulino, Bologna 1982.

- Horowitz J.L., The Decomposition of Sociology, Oxford University Press, New YorkOxford, 1993.

- Imada T., Self Organization and Society, Springer Berlin, Hedelberg, New York, 2008.

- Irti N., Nichilismo Giuridico, Laterza, Roma 2004.

- Jouxtel P., Memetica, Bollati Boringhieri, Torino, 2010.

- Kauffman A., Esplorazioni evolutive, Einaudi, Torino 2005.

- $\quad$ Kelman, A time to speak, Jossey-Bass Inc. Publishers, San Francisco, 1968.

- $\quad$ King M., Thornhil C., Niklas Luhmann's Theory of Politics and Law (Hardcover), PalgraveMacmillan, 2008.

- Kurzweil R., La singolarità è vicina, Apogeo, Milano, 2008.

- Kurzweil R., La singolarità, in Brockman Garzanti, Milano, 2005.

- Kuznets S., Popolazione, tecnologia, sviluppo, il Mulino, Bologna, 1990.

- $\quad$ Lakoff G., Nunez R. E., Da dove viene la matematica, Bollati Boringhieri, Torino, 2005.
- $\quad$ Lasch C., La ribellione delle élite, Feltrinelli, Milano 2001.

- $\quad$ Laszlo E., La sfida dell'epoca, Sperling \& Kupfer 1991.

- Laszlo E., La visione sistemica del mondo, Gruppoinsieme, Milano, 1991.

- Laszlo E., Navigare nella turbolenza, Franco Angeli, Milano, 1994.

- Laszlo E., Systems and societies, in G. Altmann-W. (Eds) Koch 1998.

- Laszlo E., Terzo Millennio: la sfida e la visione, Corbaccio, Milano, 1998.

- Laszlo E., Il pericolo e l'opportunità, Aracne, Roma, 2008.

- Laszlo E., Worldshift, Franco Angeli, Milano, 2008.

- Luhmann N., Amore come passione, Laterza, Bari, 1983.

- Luhmann N., Come è possibile l'ordine sociale?, Laterza, Bari, 1983.

- Luhmann N., Comunicazione ecologica, Franco Angeli, Milano, 1989.

- Luhmann N., La differenziazione del diritto, il Mulino, Bologna, 1990.

- Luhmann N., Sistemi sociali, il Mulino, Bologna, 1990.

- Luhmann N., Stato di diritto e sistema sociale, Guida, Napoli 1990.

- Luhmann N., "Perché Agil?", in Teoria Sociologica, n. 1, Franco Angeli, Milano, 1993.

- Luhmann N., Organisation und Entscheidung, WDV, Opladen, 1995.

- Luhmann N., Osservazioni sul moderno, Armando, Roma, 1995.

- Luhmann N., Die Gesellschaft der Gesellschaft, Suhrkamp Verlag, Germany, 1997.

- Luhmann N., Die Wirtschaft der Gesellschaft, Suhrkamp, Frankfurt am Main, 1999.

- Luhmann N., Essays on self Reference, Columbia University Press, New York, 1999.

- Luhmann N., La realtà dei mass media, Franco Angeli, Milano, 2000.

- Magatti M., Libertà Immaginaria, Feltrinelli, Milano, 2009.

- Maggioni G., Percorsi di sociologia del diritto, Liguori, Napoli, 2008.

- Mandelbrot B., Gli oggetti frattali, Einaudi, Torino, 2000.

- $\quad$ Mandelbrot B., Il disordine dei mercati, Einaudi, Torino, 2005.

- Maturana H. , Autocoscienza e realtà, Cortina, Milano, 1993. 
- Maturana H., Varela F., Autopoiesi e cognizione, Marsilio, Padova, 1985.

- Maturana H.; Varela F., Macchine ed esseri viventi, Astrolabio, Roma 1992.

- Melossi D. (a cura), Migrazioni, interazioni e conflitti nella costituzione di una democrazia europea, Giuffrè, Milano, 2003.

- $\quad$ Merton R.K, Teoria e struttura sociale, il Mulino, Bologna 1983.

- Meyer C., Davis S., Bioeconomia, MCFOlivares, Milano, 2003.

- Mintzberg H., La progettazione dell'organizzazione aziendale, il Mulino, Bologna, 1996.

- Monod J., Il caso e la necessità, Mondadori, Milano, 1979.

- $\quad$ Morecroft J., Strategic Modelling and Business Dynamics- A Feedback system Approach- J. Wiley \& Sons, Chichester, 2007.

- Morin E., Introduzione al pensiero complesso, Sperling \& Kupfer, Milano, 1993.

- Muench R., Akademische Kapitalismus, Suhrkamp Verlag, Frankfurt am Main, 2008.

- Nash J., Nichilismo e cultura, il Mulino, Bologna 1982.

- Nash J., Giochi non cooperativi e altri scritti, Zanichelli, Bologna, 2004.

- Nicolis G., Prigogine I. , La complessità, Einaudi, Torino, 1991.

- Normann R., Ridisegnare l'impresa, Etas, Milano, 2002.

- Nowotny H., Curiosità insaziabile, Codice, Torino 2006.

- Nowotny H., Insatiable CuriosityInnovation in a Fragile Future, - Cambridge ,USA and London, UK, 2008.

- Nowotny H., Testa G., Die glaesenen Gene, Suhrkamp Verlafg, Frankfurt am Main, 2009.

- Ortega y Gasset, Miseria e splendore della traduzione, Il Melangolo, Genova, 2001.

- Ostrom E., Governare $i$ beni collettivi. Istituzioni pubbliche e iniziative delle comunità, Marsilio, Roma 2006.

- Piaget J., L'epistemologia genetica, Sagittari Laterza, Bari, 2000.

- $\quad$ Pitasi A., "A Facilitative Agenda Setting For the Evolutionary Strategies of the $21^{\text {st }}$ Century", World Futures, vol. 54, 1999.

- $\quad$ Pitasi A., Universi paralleli. Saperi della pubblica amministrazione, cambiamento sociale e stili di vita dei cittadini, Franco Angeli, Milano, 2003.

- $\quad$ Pitasi A., Sfide del nostro tempo, Aracne, Roma, 2007.
- $\quad$ Pitasi A., Un seimiliardesimo di umanità, Guerini Scientifica, Milano, 2008.

- Pitasi A., "Il Tempo Zero dell'alta formazione", in Pitasi A. (a cura di), Verso l'economia della conoscenza, Loffredo, Napoli, 2008.

- $\quad$ Pitasi A., Teoria dei sistemi e complessità morfogenetica del capitalismo, Aracne, Roma, 2010.

- $\quad$ Pitasi A., Le monde hyperhumain. Systèmes juridiques et changement social, L'Harmattan, Paris 2011.

- Pitasi A. (Ed.), "Future Trends of Communication Strategies", in World Futures Journal of the General Evolution Research Group, 3 issues, volume 57, numbers 4,5 and 6 (8), Gordon \& Breach Publishing Co.-Taylor \& Francis Co., New York, 2001

- Pitasi A. (Ed.), "The Communication Strategies of the Globalized Individual", in Id. (ed.), The Future Trends of Communication Strategies", in World Futures, vol. 57, Taylor \& Francis, New York, 2001.

- $\quad$ Pitasi A., Ferone E. , Il tempo zero del desiderio, McGraw Hill, Milano, 2008.

- $\quad$ Pocar V., Il diritto e le regole sociali, Guerini \& associati, Milano, 1997.

- $\quad$ Pocar V., Guida al diritto contemporaneo, Laterza, Roma-Bari, 2002.

- $\quad$ Rajola F. , Manuale dell'innovazione, Il Sole 24 ore, Milano, 2006

- Rodriguez M. D., Torres J., Nafarrate, Introducion a la teoria de la sociedad de Niklas Luhnmann, Editorial Herder, Ciudad de Mexico, 2008.

- $\quad$ Rogers E. , Diffusion of Innovation, The Free Press, Glencoe, 1956.

- $\quad$ Ronen B. Pass S., Rinnovare l'azienda a costo zero, EGEA, Milano 2009.

- Ronfani P. (a cura di), Non è giusto, Donzelli, Roma. 2007.

- Savona E.U., Mezzanotte L., La corruzione in Europa, Carocci, Roma, 2002.

- $\quad$ Schelling T.C., Micromotivazioni della vita quotidiana, Bompiani, Milano, 2008.

- Schuermann R., Dai principi all'anarchia, il Mulino, Bologna 1995.

- Schumpeter J.A., Capitalismo, socialismo, democrazia, Etas, Milano, 2001.

- $\quad$ Schumpeter J.A., Teoria dello sviluppo economico, Etas, Milano 2002.

- Seabright P., In compagnia degli estranei, Codice, Torino, 2005.

- $\quad$ Seidl C., Beutelmeyer W., Die Marke ICH, Ueberreuter, Francoforte e Vienna, 1999. 
- $\quad$ Sennett R., La cultura del nuovo capitalismo, il Mulino, Bologna 2006.

- Siegel J. , The Future for Investors, Crown Business, New York, 2005.

- $\quad$ Simmel G., La moda e altri saggi di cultura filosofica, Longanesi, Milano, 1985.

- Simon H., Scienza economica e comportamento umano, Edizioni di Comunità, Milano, 2000.

- Sokal A., Bricmont J., Imposture intellettuali, Garzanti, Milano, 1997.

- $\quad$ Stewart T., Il capitale intellettuale, Ponte alle Grazie, Milano, 1999.

- $\quad$ Stewart J., La ricchezza del sapere, Ponte alle Grazie, Milano 2001.

- $\quad$ Stiglitz J.E., Informazione, economia pubblica e macroeconomia, il Mulino, Bologna 2002.

- $\quad$ Swedberg R., Economia e sociologia, Donzelli, Roma 1994.

- $\quad$ Swedberg R., Joseph A., Schumpeter: His Life and Work, Cambridge: Polity Press and Oxford: Basil 1991.

- $\quad$ Terna P. et al (a cura di), Modelli per la complessità, il Mulino, Bologna, 2006.
- Thurow L.C., La costruzione della ricchezza, Ilsole24ore, Milano 2000.

- $\quad$ Tort P., Effetto Darwin, Angelo Colla Editore, Vicenza, 2009.

- Trobia A., La sociologia come scienza rigorosa, Angeli, Milano, 2001.

- $\quad$ Varela F.J., Thompson E., Rosch E., La via di mezzo della conoscenza, Feltrinelli, Milano, 1992.

- Villani G., Complesso e organizzato, Angeli, Milano, 2008.

- Von Foerster H. , Sistemi che osservano, Astrolabio, Roma, 1987.

- Von Glasersfeld E., Costruttivismo radicale, Società Stampa Sportiva, RomaVon, 1995

- Weick K. E., Senso e significato nell'organizzazione, Raffaello Cortina Editore, Milano, 1997.

- Williamson O., L'organizzazione Economica. Imprese, mercati e controllo politico, il Mulino, Bologna, 1991. 